Click www.researchjournal.co.in/online/subdetail.html to purchase.

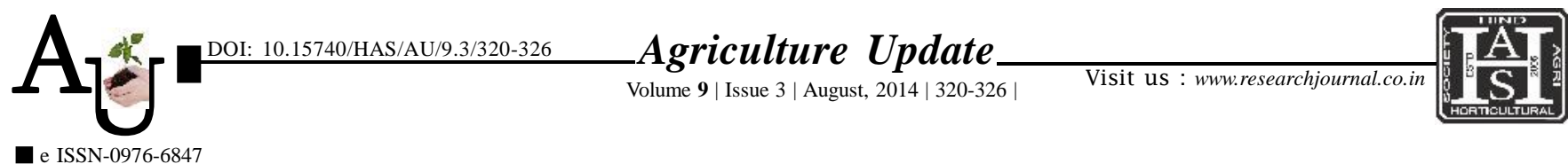

\title{
Research Article Bitter gourd growers pesticides use pattern in controlling insect-pests and diseases in Nadia district of West Bengal
}

\author{
MIRALAL JANA
}

\begin{abstract}
Article Chronicle: Summary : Indiscriminate use of chemicals in agriculture during post green revolution period and their adverse Received :

16.05.2014;

Revised :

03.06.2014;

Accepted :

19.06.2014

KEY WoRDS: Pesticides, Chemical name, Commercial effect on soil health and environment has created an alarming situation. A situation has resulted which urgently demands an environmentally safe, sustainable and simultaneously, economically viable production system. This indeed is essential for optimizing production and at the same time to minimize threat to environment. Considering the importance of the study, the objective, to portray the pesticides use pattern in bitter gourd in controlling insect-pests and diseases was undertaken. The study was conducted in Nadia district of West Bengal. For the selection of area and respondents of the present study, multi-stage random sampling technique and universe method were adopted. The study reveals that the most harmful insect-pest of bitter gourd crop was pumpkin fruit fly, downy mildew disease was the most damaging disease, bitter gourd growers were using various brands of various technical grade of pesticides for controlling insect-pests and diseases with several doses, infestation of insect-pests and diseases was mainly seen on mature stage of the crop, main source of information on pesticides use was agricultural input retailers, the bitter gourd growers used 40-60 lit. and 60-90 lit. of water per bigha of land ( 1 acre $=3$ bighas) for spraying at seedling stage and mature stage, respectively, their interval of spraying of chemicals was mainly 4-7 days and spraying was most popular method of application of pesticides. Therefore, on the basis of the present investigation, the various extension agencies those are working in the study area should reorient their extension strategies accordingly.
\end{abstract} name, Use pattern, Bitter gourd growers, Insect-pests, Diseases, Sustainable agriculture

How to cite this article : Jana, Hiralal (2014). Bitter gourd growers pesticides use pattern in controlling insect-pests and diseases in Nadia district of West Bengal. Agric. Update, 9(3): 320-326.

Author for correspondence :

HIRALAL JANA

Department of Extension

Education, N.M. College of

Agriculture, Navsari

Agricultural University,

NAVSARI (GUJARAT)

INDIA

Email:janahiralal@

yahoo.in 